Review Article

\title{
Recent Advances in the Cancer Drug Delivery: Nanocarrier Approach
}

\author{
Deepak Prashar*, Poonam \\ LR Institute of Pharmacy, Jabeli Kyar, Solan (HP), India. \\ *Corresponding author's E-mail: prashardeepak99@yahoo.in
}

Received: 10-05-2021; Revised: 22-06-2021; Accepted: 27-06-2021; Published on: 15-07-2021.

ABSTRACT

The present review work tries to explore the present status of the nano carriers in the delivery of anti cancer drugs. The shortcomings associated with the anticancer drugs like poor solubility, multiple resistance and less bioavailability is been investigating using different nano formulations. The recent advance work on nanoparticles for the delivery of anti tumor drugs is focused along with the different patents available. The different technologies available in the present scenario for the delivery of anti-cancers drugs are being highlightened.

Keywords: Cancer, Nanocarriers, Patents, Advances, Techniques.

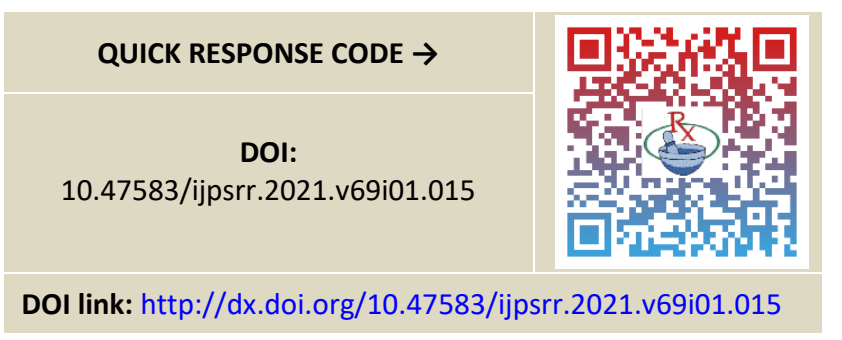

\section{INTRODUCTION}

C

ancer is a menace which needed to be cured at the earliest. The cancer treatment and management can be done though chemotherapy, radiotherapy, surgery and nutraceuticals. The main predicament with chemotherapy is that it has restricted accessibility of drugs to the cancerous tissues which needs high doses. Moreover, the drugs may produce intolerable toxicity and may even develop multiple drug resistance. The conventional dosing also presents non-specific targeting of the delivered drug. There are the numerous types of the cancer which are being prevailing in the present scenario. Each type of cancer requires specific drug scheduling and delivery methodology. The advancement in nanotechnology has provided the researchers and physicians with the benefits of delivering the drugs to targeted tissues and that too with better retention time and enhanced bioavailability. The nano drug delivery system improves the pharmacokinetics of the loaded poorly soluble drug which is hydrophobic in nature and made it compatible for drug targeting. There are the numerous nanoparticles, including liposomes, niosomes, cubosomes, polyniosomes, polymeric nanoparticles, dendrimers, magnetic and other inorganic nanoparticles which are available as per the requirement of the drug and delivery route.

\section{Drugs For Treatment of Cancer}

There are the large numbers of drugs that can be used for the treatment of cancer. This huge number too presents the problem in selecting the appropriate dose and delivery route. Additionally, these drugs are accompanied with large number of formulation problems which needed to be resolved before the commercialization of the drug candidate.

Table 1: Commercially Available Drugs for The Treatment of Cancer ${ }^{8}$
Alphabetical
Anti-Cancer Drugs
Order
A.
ABVD, AC, Abemaciclib (Verzenois), Abiraterone (Zytiga), Abraxane, Abstral, Actinomycin D, Actiq, Adriamycin, Afatinib (Giotrif), Afinitor, Aflibercept (Zaltrap), Aldara, Aldesleukin (IL-2, Proleukin or interleukin 2), Alectinib (Alecensa), Alemtuzumab (Campath, MabCampath), Alkeran, Amsacrine (Amsidine, m-AMSA), Amsidine, Anastrozole (Arimidex), Ara C, Aredia, Arimidex, Aromasin, Arsenic trioxide (Trisenox, ATO), Asparaginase (Crisantaspase, Erwinase), Atezolizumab (Tecentriq), Avelumab (Bavencio), Axitinib (Inlyta), Azacitidine (Vidaza)
B. BEACOPP, BEAM, Bendamustine (Levact), Bevacizumab (Avastin), Bexarotene (Targretin), Bicalutamide (Casodex), Bleomycin, Bleomycin, etoposide and platinum (BEP), Blinatumomab (Blincyto), Bortezomib (Velcade), Bosulif, Bosutinib (Bosulif), Brentuximab (Adcetris), Brufen, Buserelin (Suprefact), Busilvex, Busulfan (Myleran, Busilvex) 
C. CAPE-OX, CAPOX, CAV, CCNU, CHOP, CMF, CMV, CVP, Cabazitaxel (Jevtana), Cabozantinib (Cometriq, Cabometyx), Caelyx, Calpol, Campto, Capecitabine (Xeloda), Caprelsa, CarboTaxol, Carboplatin, Carboplatin and etoposide, Carboplatin and paclitaxel, Carmustine (BCNU), Casodex, Ceritinib (Zykadia), Cerubidin, Cetuximab (Erbitux), ChIVPP, Chlorambucil (Leukeran), Cisplatin, Cisplatin and capecitabine (CX), Cisplatin and fluorouracil (5FU), Cisplatin, etoposide and ifosfamide (VIP), Cisplatin, fluorouracil (5FU) and trastuzumab, Cladribine (Leustat, LITAK), Clasteon, Clofarabine (Evoltra), Co-codamol (Kapake, Solpadol, Tylex), Cometriq, Cosmegen, Crisantaspase, Crizotinib (Xalkori), Cyclophosphamide, Cyclophosphamide, thalidomide and dexamethasone (CTD), Cyprostat, Cyproterone acetate (Cyprostat), Cytarabine (Ara C, cytosine arabinoside), Cytarabine into spinal fluid, Cytosine arabinoside

D. DHAP, DTIC, Dabrafenib (Tafinlar), Dabrafenib (Tafinlar) and Trametinib (Mekinist), Dacarbazine (DTIC), Dacogen, Dactinomycin (actinomycin D, Cosmegen Lyovac), Dasatinib (Sprycel), Daunorubicin, Decapeptyl SR, Decitabine (Dacogen), Degarelix (Firmagon), Denosumab (Prolia, Xgeva), Depocyte, Dexamethasone, Diamorphine, Disodium pamidronate, Disprol, Docetaxel (Taxotere), Docetaxel, cisplatin and fluorouracil (TPF), Doxifos, Doxil, Doxorubicin, Doxorubicin and ifosfamide (Doxifos), Drogenil, Durogesic, Durvalumab (Imfinzi)

E. EC, ECF, EOF, EOX, EP, ESHAP, Effentora, Efudix, Eldisine, Eloxatin, Encorafenib (Braftovi) and Binimetinib (Mektovi), Enzalutamide (Xtandi), Epirubicin (Pharmorubicin), Epirubicin, carboplatin and capecitabine (ECarboX), Epirubicin, cisplatin and capecitabine (ECX), Erbitux, Eribulin (Halaven), Erlotinib (Tarceva), Erwinase, Estracyt, Etopophos, Etoposide (Etopophos, Vepesid), Everolimus, Evoltra, Exemestane (Aromasin)

F. FEC, FMD, FOLFIRINOX, Faslodex, Femara, Fentanyl, Firmagon, Fludara, Fludarabine (Fludara), Fludarabine, cyclophosphamide and rituximab (FCR), Fluorouracil (5FU), Fluorouracil (5FU) and mitomycin C, Fluorouracil, epirubicin, cyclophosphamide and docetaxel (FEC-T), Flutamide, Folinic acid, fluorouracil and irinotecan (FOLFIRI), Folinic acid, fluorouracil and oxaliplatin (FOLFOX), Fulvestrant (Faslodex)

G. G-CSF, Gefitinib (Iressa), GemCarbo (gemcitabine and carboplatin), GemTaxol, Gemcitabine (Gemzar), Gemcitabine and capecitabine (GemCap), Gemcitabine and cisplatin (GC), Gemcitabine and paclitaxel (GemTaxol), Gemzar, Giotrif, Gliadel (carmustine wafers), Glivec, Gonapeptyl Depot, Goserelin (Zoladex) for breast cancer, Goserelin (Zoladex) for prostate cancer, Granulocyte colony stimulating factor (G-CSF)

H. Halaven, Herceptin, Hycamtin, Hydrea, Hydroxycarbamide (Hydrea), Hydroxyurea

I. I-DEX, ICE, IL-2, IPE, Ibandronic acid (Bondronat), Ibrutinib (Imbruvica), Ibuprofen (Brufen, Nurofen), Iclusig, Idarubicin (Zavedos), Idarubicin and dexamethasone, Idelalisib (Zydelig), Ifosfamide (Mitoxana), Imatinib (Glivec), Imiquimod cream (Aldara), Inotuzumab ozogamicin (Besponsa), Instanyl, Interferon alfa (IntronA, Roferon-A), Interleukin, Intron A, Ipilimumab (Yervoy), Ipilimumab and nivolumab, Iressa, Irinotecan (Campto), Irinotecan and capecitabine (XELIRI), Irinotecan de Gramont, Irinotecan modified de Gramont

J. Javlor, Jevtana

K. Kadcyla, Kapake, Keytruda

L. Lanreotide (Somatuline), Lanvis, Lapatinib (Tyverb), Lenalidomide (Revlimid), Lenvatinib (Lenvima, Kisplyx), Letrozole (Femara), Leukeran, Leuprorelin (Prostap, Lutrate), Leustat, Levact, Liposomal doxorubicin, Litak, Lomustine (CCNU), Lynparza, Lysodren

M. MIC, MMM, MST Continus, MVAC, MVP, MabCampath, Mabthera, Maxtrex, Medroxyprogesterone acetate (Provera), Megace, Megestrol acetate (Megace), Melphalan (Alkeran),, Melphalan, prednisolone and thalidomide (MPT), Mepact, Mercaptopurine (Xaluprine), Methotrexate, Methyl prednisolone, Mifamurtide (Mepact), Mitomycin C, Mitotane, Mitoxana, Mitoxantrone (Mitozantrone), Modified de Gramont, Morphgesic SR, Morphine, Myleran, Myocet, m-AMSA

N. Nab-paclitaxel, Nab-paclitaxel (Abraxane), Navelbine, Nelarabine (Atriance), Neratinib (Nerlynx), Nexavar, Nilotinib (Tasigna), Nintedanib (Vargatef), Nipent, Niraparib (Zejula), Nivolumab (Opdivo), Novgos, Nurofen

O. Obinutuzumab (Gazyvaro), Octreotide (Sandostatin), Olaparib (Lynparza), Oncovin, Onkotrone, Opdivo, Oramorph, OxCap, Oxaliplatin (Eloxatin), Oxaliplatin and capecitabine (XELOX)

P. PC (paclitaxel and carboplatin, CarboTaxol), PCV, PE, PMitCEBO, POMB/ACE, Paclitaxel (Taxol), Paclitaxel and carboplatin, Palbociclib (Ibrance), Pamidronate, Panadol, Panitumumab (Vectibix), Paracetamol, Pazopanib (Votrient), Pembrolizumab (Keytruda), Pemetrexed (Alimta), Pemetrexed and carboplatin, Pemetrexed and cisplatin, Pentostatin (Nipent), Perjeta, Pertuzumab (Perjeta), Pixantrone (Pixuvri), Pixuvri, Pomalidomide 
and dexamethasone, Ponatinib (Iclusig), Potactasol, Prednisolone, Procarbazine, Proleukin, Prolia, Prostap, Provera, Purinethol

Q.

R. R-CHOP, R-CVP, R-DHAP, R-ESHAP, R-GCVP, RICE, Raloxifene, Raltitrexed (Tomudex), Regorafenib (Stivarga), Revlimid, Ribociclib (Kisqali), Rituximab (Mabthera, Rixathon, Truxima), Rucaparib (Rubraca), Ruxolitinib

S. Sevredol, Sodium clodronate (Bonefos, Clasteon, Loron), Solpadol, Sorafenib (Nexavar), Steroids (dexamethasone, prednisolone, methylprednisolone and hydrocortisone), Streptozocin (Zanosar), Sunitinib (Sutent), Sutent

T. TAC, TIP, Tafinlar, Talimogene laherparepvec (T-VEC), Tamoxifen, Tarceva, Targretin, Tasigna, Taxol, Taxotere, Taxotere and cyclophosphamide (TC), Temodal, Temozolomide (Temodal), Temsirolimus (Torisel), Tepadina, Thalidomide, Thiotepa (Tepadina), Tioguanine, Tomudex, Topotecan (Hycamtin, Potactasol), Torisel, Trabectedin (Yondelis), Trastuzumab, Trastuzumab and pertuzumab, Trastuzumab emtansine (Kadcyla), Treosulfan, Tretinoin (Vesanoid, ATRA), Trifluridine and tipiracil (Lonsurf), Triptorelin (Decapeptyl SR, Gonapeptyl Depot), Trisenox, Tylex, Tyverb

U.

V. VIDE, Vandetanib (Caprelsa), Vargatef, VelP, Vectibix, Velbe, Velcade, Vemurafenib (Zelboraf), Vepesid, Vesanoid, Vidaza, Vinblastine (Velbe), Vincristine, Vincristine, actinomycin D (dactinomycin) and cyclophosphamide (VAC), Vincristine, actinomycin D and ifosfamide (VAI), Vincristine, doxorubicin and dexamethasone (VAD), Vindesine (Eldisine), Vinorelbine (Navelbine), Votrient

w.

X. XELOX, Xalkori, Xeloda, Xgeva, Xtandi

Y. Yervoy, Yondelis

Z. Z-DEX, Zaltrap, Zanosar, Zavedos, Zelboraf, Zevalin, Zoladex (breast cancer), Zoladex (prostate cancer), Zoledronic acid (Zometa), Zometa, Zomorph, Zydelig, Zytiga

\section{Presently Available Drug Delivery Technologies For Cancer 9}

In the present scenario to overcome the associated problems with the cancer treatment, the numbers of technologies have been utilized. Depending upon the drug candidates the different approaches have been specified though research and commercially employed. By using these technologies the commercial applicability and retention time of the drug candidates can increased and at the same time pharmacokinetics of the drugs can modified as desired.

\section{Lipid Based Systems}

$\checkmark$ Lipid Based Emulsion

$\checkmark$ Conventional Liposomes

$\checkmark \quad$ Long circulating Liposomes

$\checkmark \quad$ pH-sensitive Liposomes

$\checkmark$ Immunoliposomes

$\checkmark$ Solid Lipid Nanoparticle

\section{Specific Strategies}

$\checkmark$ Antibody based therapy

$\checkmark$ Carbohydrate based therapy

$\checkmark$ Delivery of proteins and peptides $\checkmark \quad$ RGD based formulations

$\checkmark \quad$ Albumin based drug carrier

$\checkmark$ Anti-angiogenesis therapy

$\checkmark \quad$ Fatty acid as a targeting vector

$\checkmark$ Tumour active prodrug therapy

$\checkmark$ Heat activated targeted drug delivery

$\checkmark$ PEG technologies

$\checkmark \quad$ Biodegradable polymeric devices

$\checkmark$ Angiolytic agents

3. Polymeric Systems

$\checkmark \quad$ Nanoparticles

$\checkmark$ Microspheres

$\checkmark$ Stealth Nanoparticles

$\checkmark$ Drug-polymer conjugate

$\checkmark$ Polymer-DNA complexes

$\checkmark$ Polymer-protein conjugate

$\checkmark$ Dendrimers- Dendrons, stealth dendrimer, Diblock \& Triblock dendritic copolymers

$\checkmark$ Micelles-Immuno micelles, thermo-responsive micelles, $\mathrm{pH}$ responsive micelles 
4. Biological Therapies

$\checkmark$ Genetically Modified Bacteria

$\checkmark$ RNA Interference

$\checkmark$ Antisense Therapy

$\checkmark$ Gene Therapy

\section{Patents in Cancer Therapies ${ }^{10-24}$}

The advantages of the patents have boosted many companies and researchers to make new advancements in the field of cancer research therapy. In the lieu of that many companies have filed the patents in the field of cancer research and advancements in the past few years. The patents are further being assigned and are being rented by the patenting companies to earn profits too.

Table 2: Patents Filed for Treatment of Cancer

\begin{tabular}{|c|c|c|c|c|c|}
\hline S. No. & Title of Patent & Patent ID & Inventor & Status & $\begin{array}{l}\text { Current } \\
\text { Assignee }\end{array}$ \\
\hline 1. & $\begin{array}{l}\text { Cancer treatment } \\
\text { method }\end{array}$ & $\begin{array}{l}\text { US4622952A } \\
\text { United States (1986) }\end{array}$ & Robert T. Gordon & Expired & $\begin{array}{l}\text { Gordon David } \\
\text { Skokie Illinois }\end{array}$ \\
\hline 2. & $\begin{array}{l}\text { Cure for cancer (salicylic } \\
\text { acid) }\end{array}$ & $\begin{array}{l}\text { US20040248858A1 } \\
\text { United States (2004) }\end{array}$ & Kaumil Parghi & Abandoned & ------ \\
\hline 3. & $\begin{array}{l}\text { Apparatus for } \\
\text { treatment of cancer } \\
\text { with photodiode }\end{array}$ & $\begin{array}{l}\text { US4822335A } \\
\text { United States (1989) }\end{array}$ & $\begin{array}{l}\text { Yoshio Kawai } \\
\text { Kazue Endo } \\
\text { Makoto Yoshimura }\end{array}$ & Expired & Kureha Corp \\
\hline 4. & $\begin{array}{l}\text { Method for initiation of } \\
\text { tumor cell death by } \\
\text { chlorine-e6, ascorbic } \\
\text { acid and hf- and shf- } \\
\text { energy }\end{array}$ & $\begin{array}{l}\text { RU2739252C2 } \\
\text { Russia } \\
\text { (2020) }\end{array}$ & $\begin{array}{l}\text { Tsuglenok Nikolay } \\
\text { Vasilievich }\end{array}$ & $\begin{array}{l}\text { Application } \\
\text { granted }\end{array}$ & $\begin{array}{l}\text { Tsuglenok } \\
\text { Nikolay } \\
\text { Vasilievich }\end{array}$ \\
\hline 5. & $\begin{array}{l}\text { Method for initiating } \\
\text { the death of tumor cells } \\
\text { with sodium salts of } \\
\text { chlorine-e6, chlorine-p6 } \\
\text { and purpurin-5 and hf } \\
\text { and microwave } \\
\text { radiation with wave } \\
\text { radiation energy }\end{array}$ & $\begin{array}{l}\text { RU2724326C2 } \\
\text { Russia (2020) }\end{array}$ & $\begin{array}{l}\text { Tsuglenok Nikolay } \\
\text { Vasilievich }\end{array}$ & $\begin{array}{l}\text { Application } \\
\text { granted }\end{array}$ & $\begin{array}{l}\text { Tsuglenok } \\
\text { Nikolay } \\
\text { Vasilievich }\end{array}$ \\
\hline 6. & $\begin{array}{l}\text { Method for initiation of } \\
\text { tumor cell death by } \\
\text { demethylglucamic acid } \\
\text { chlorine-e6 and hf and } \\
\text { shf wave energy } \\
\text { radiation }\end{array}$ & $\begin{array}{l}\text { RU2723882C2 } \\
\text { Russia (2020) }\end{array}$ & $\begin{array}{l}\text { Tsuglenok Nikolay } \\
\text { Vasilievich }\end{array}$ & $\begin{array}{l}\text { Application } \\
\text { granted }\end{array}$ & $\begin{array}{l}\text { Tsuglenok } \\
\text { Nikolay } \\
\text { Vasilievich }\end{array}$ \\
\hline 7. & $\begin{array}{l}\text { Method of initiating the } \\
\text { death of tumor cells } \\
\text { with sodium chloride } \\
\text { chlorine-e6, succinic } \\
\text { acid and hf and shf } \\
\text { wave radiation energy }\end{array}$ & $\begin{array}{l}\text { RU2723884C2 } \\
\text { Russia (2020) }\end{array}$ & $\begin{array}{l}\text { Tsuglenok Nikolay } \\
\text { Vasilievich }\end{array}$ & $\begin{array}{l}\text { Application } \\
\text { granted }\end{array}$ & $\begin{array}{l}\text { Tsuglenok } \\
\text { Nikolay } \\
\text { Vasilievich }\end{array}$ \\
\hline 8. & $\begin{array}{l}\text { Method for initiation of } \\
\text { tumor cell death by 5- } \\
\text { aminolevuleic acid and } \\
\text { hf and uhf radiation } \\
\text { wave energy }\end{array}$ & $\begin{array}{l}\text { RU2723680C2 } \\
\text { Russia (2020) }\end{array}$ & $\begin{array}{l}\text { Tsuglenok Nikolay } \\
\text { Vasilievich }\end{array}$ & $\begin{array}{l}\text { Application } \\
\text { granted }\end{array}$ & $\begin{array}{l}\text { Tsuglenok } \\
\text { Nikolay } \\
\text { Vasilievich }\end{array}$ \\
\hline 9. & $\begin{array}{l}\text { Treating cancer using } \\
\text { electromagnetic fields } \\
\text { in combination with } \\
\text { photodynamic therapy }\end{array}$ & $\begin{array}{l}\text { US8465533B2 } \\
\text { United States (2013) }\end{array}$ & Yoram Palti & Active & $\begin{array}{l}\text { Novocure } \\
\text { GmbH } \\
\text { Bpcr LP }\end{array}$ \\
\hline
\end{tabular}




\begin{tabular}{|c|c|c|c|c|c|}
\hline 10. & $\begin{array}{l}\text { Treating cancer using } \\
\text { electromagnetic fields } \\
\text { in combination with } \\
\text { other treatment } \\
\text { regimens }\end{array}$ & $\begin{array}{l}\text { US20070239213A1 } \\
\text { United States } \\
(2007)\end{array}$ & Yoram Palti & Active & $\begin{array}{l}\text { Novocure } \\
\text { GmbH } \\
\text { Bpcr LP }\end{array}$ \\
\hline 11. & $\begin{array}{l}\text { Treatment of cancer } \\
\text { with interferon and } \\
\text { radiotherapy }\end{array}$ & $\begin{array}{l}\text { US4846782A } \\
\text { United States (1989) }\end{array}$ & Eric Bonnem & Expired & $\begin{array}{l}\text { Merck Sharp } \\
\text { and } \\
\text { Corp }\end{array}$ \\
\hline 12. & $\begin{array}{l}\text { Method of treating } \\
\text { malignant tumors }\end{array}$ & $\begin{array}{l}\text { SU522688A1 } \\
\text { USSR - Soviet Union } \\
\text { (1977) }\end{array}$ & $\begin{array}{l}\text { A.K. Pankov } \\
\text { M.A. Ukolova } \\
\text { E.B. Kvakina } \\
\text { L.Kh. Harkavi } \\
\text { E.I. Brazhnikov } \\
\text { R.N. Salads } \\
\text { G.R. Solovyova } \\
\text { V.A. Eremin }\end{array}$ & $\begin{array}{l}\text { Application } \\
\text { granted }\end{array}$ & ------------------ \\
\hline 13. & Electrochemotherapy & $\begin{array}{l}\text { US5468223A } \\
\text { United States } \\
(1995)\end{array}$ & Lluis Mir & Expired & $\begin{array}{l}\text { Centre } \\
\text { National de la } \\
\text { Recherche } \\
\text { Scientifique }\end{array}$ \\
\hline 14. & $\begin{array}{l}\text { Apparatus and method } \\
\text { for treating a tumor or } \\
\text { the like }\end{array}$ & $\begin{array}{l}\text { US20040068296A1 } \\
\text { United States (2006) }\end{array}$ & Yoram Palti & Active & $\begin{array}{l}\text { Novocure } \\
\text { GmbH } \\
\text { Bpcr LP }\end{array}$ \\
\hline 15. & $\begin{array}{l}\text { Breast cancer } \\
\text { detection, imaging and } \\
\text { screening by } \\
\text { electromagnetic } \\
\text { millimeter waves }\end{array}$ & $\begin{array}{l}\text { US5807257A } \\
\text { United States } \\
(1998)\end{array}$ & Jack E. Bridges & Expired & Interstitial LLC \\
\hline
\end{tabular}

\section{Recent Nanoparticles Encapsulated Anticancer Drug Formulations and Advanced Technologies}

The review of literature suggested that the numbers of formulations are available in the market with encapsulated drugs for the treatment of malignancies. Even the literature review also suggested that the whole grain products too are very essential for the body and can be used for the treatment of cancer along with the drugs 25-30. The advancement in the anti-cancer therapy started with development of nano-sciences. The physical properties of most of the drugs used in the treatment of cancer can be altered by using nanotechnological approach.

Fouladi et al., 2017 developed the enzyme- responsive liposomes for the delivery of anticancer drugs. Enzymeresponsive liposomes release their encapsulated drugs upon contact with the enzyme through several destabilization mechanisms ${ }^{31}$.

Sapra and Allen 2003 developed the ligand targeted anticancer drugs formulation. The prepared formulation using antibody showed increased therapeutic index of anti cancer drugs ${ }^{32}$.
Shim et al., 2011 developed Trilysinoyl oleylamide-based cationic liposomes for systemic co-delivery of siRNA and an anticancer drug. The formulation showed the highest delivery efficiency combined with minimal cytotoxicity ${ }^{33}$.

Kim et al., 2008 studied the antitumor efficacy of cisplatinloaded glycol chitosan nanoparticles in tumor bearing mice. The results indicate that $\mathrm{HGC}$ nanoparticles are a promising carrier for the anticancer drug $\mathrm{CDDP}^{34}$.

Feng et al., 2013 generated the Chitosan/o-carboxymethyl chitosan nanoparticles for efficient and safe oral anticancer drug delivery. Further, the in vitro and in vivo evaluation was also carried out to optimize the results ${ }^{35}$.

Kim et al., 2016 developed Doxorubicin/gold-loaded core/shell nanoparticles for combination therapy to treat cancer through the enhanced tumor targeting ${ }^{36}$.

Xiang et al., 2021 prepared and studied Polyphenolcisplatin complexation forming core-shell nanoparticles with improved tumor accumulation and dual-responsive drug release for enhanced cancer chemotherapy. PEGGAx/Pt nanoparticles exhibited improved antitumor efficiency against 4 T1 breast cancer and A549 lung 
carcinoma with much-reduced toxicity compared to free $\mathrm{CDDP}^{37}$.

Kim et al., 2021 developed the combination of cancerspecific prodrug nanoparticle with $\mathrm{Bcl}-2$ inhibitor to overcome acquired drug resistance. Orally administered combination Navitoclax PNPs exhibited more potent therapeutic efficacy in acquired drug resistant models than free DOX plus Navitoclax, whereas PNPs greatly reduced systemic toxic side effects in normal organs ${ }^{38}$.

Yao et al., 2020 extensively studied the role of nanotechnology in the treatment of cancer over conventional forms. The mechanisms of cancer drug resistance include over expression of drug efflux transporters, defective apoptotic pathways and hypoxic environment. Nanoparticles targeting these mechanisms can lead to an improvement in the reversal of multidrug resistance ${ }^{39}$.

$\mathrm{Xu}$ et al., 2021 developed the Zoledronic Acid-Loaded Hybrid Hyaluronic Acid/Polyethylene Glycol/NanoHydroxyapatite Nanoparticle for the treatment of osteosarcoma a malignant tumor. Results replicate that the compact and stable structure could achieve high drug loading efficiency, sustained drug release, and great biocompatibility. Further, in vitro and in vivo evaluations revealed the low cytotoxicity and acceptable immune response under low-dose nanoparticles treatment, indicating its potential application ${ }^{40}$.

Aguilar et al., 2020 designed green synthesis of nano hydroxyapatite and studied its cytotoxicity effect against fibroblast ${ }^{41}$.

$\mathrm{Au}$ et al., 2016 synthesized folate-targeted pH-responsive calcium zoledronate nanoscale metal-organic frameworks with an anticancer activity ${ }^{42}$.

Dai et al., 2015 synthesized of nanostructure containing methotrexate/hydroxyapatite. Further, the morphology, mechanism of action and bioassay study was carried out to establish its effect ${ }^{43}$.

Federman et al., 2012 studied the improved growth inhibition of osteosarcoma by cytotoxic polymerized liposomal nanoparticles targeting the alcam cell surface receptor $^{44}$.

Li et al., 2019 synthesized Zoledronic acid containing nanoparticles. This preparation showed minimum premature release with enhanced activity against extra skeletal tumor ${ }^{45}$.

Sun et al., 2017 studied the morphological effects of nanohydroxyapatite as a drug carrier of methotrexate an anti cancer agent. The results concluded that the laminated hybrid exhibits a higher drug loading capacity compared to the other two hybrids. Moreover, the result of in vitro bioassay test confirms that the inhibition efficacy of the three hybrids showed a positive correlation to the drug loading capacity ${ }^{46}$.
Yang et al., 2020 reported a novel Rhein- polyethylene glycol (PEG)-nano hydroxyapatite ( $\mathrm{nHA}$ ) conjugate to deliver doxorubicin (DOX) and Phosphorus-32 ( $\left.{ }^{32} \mathrm{P}\right)$ simultaneously for enhanced cancer chemo-radiotherapy. DOX/32P@Rhein-PEG-nHA showed the strongest inhibition on the growth of bone metastases of breast cancer ${ }^{47}$.

Chun et al., 2021 designed ovarian cancer-targeting drug delivery system based on folic acid-functionalized tea polyphenol. The preparation was evaluated both in vitro and in vivo resulting in enhanced ovarian cancer inhibition efficacy $^{48}$.

Fan et al., 2015 studied the enhanced antitumor effects by docetaxel/LL37-loaded thermo-sensitive hydrogel nanoparticles in peritoneal carcinomatosis of colorectal cancer $^{49}$.

There are several reported research and review work which suggested the utilization of nano particles like liposomes, niosomes, cubosomes etc in the delivery of anti cancer drugs. Apart from that several herbal formulations and relevant literature is also available which suggested the role of polymeric forms in the delivery of anti malignancy drugs $^{50-54}$.

\section{CONCLUSION}

Current study evidently signifying the role of nano carriers and nano particles in the delivery for anti cancer drugs. The review of the literature also suggested that the present scenario is focused on the latest techniques of drug delivery. The whole grain products too can be identified as an alternate for the treatment of cancer along with some herbal prospect. In present many magnetic and thermosenstive hydrogels are being formulated for the advanced delivery of anti cancer drugs. The study pointed out the future prospect of nanoformulations and techniques which can be utilized for cancer treatment with better alternate to conventional drug delivery system.

\section{REFERENCES}

1. Wakaskar RR. General overview of lipid-polymer hybrid nanoparticles, dendrimers, micelles, liposomes, spongosomes and cubosomes. Journal of Drug Targeting 2018; 26(4): 311-318. doi: 10.1080/1061186X.2017.1367006

2. Wei QY, Xu YM, Lau ATY. Recent Progress of NanocarrierBased Therapy for Solid Malignancies. Cancers (Basel) 2020; 12(10): 2783. doi:10.3390/cancers12102783

3. https://www.futuremedicine.com/doi/abs/10.2217/nnm.10 .117

4. Wu B, Lu ST, Deng K, Yu H, Cui C, Zhang Y, Wu M, Zhuo R, Xu $\mathrm{H}$, Huang S. MRI-guided targeting delivery of doxorubicin with reduction-responsive lipid-polymer hybrid nanoparticles. International Journal of Nanomedicine 2017; 12: 6871-6882. doi: 10.2147/IJN.S143048

5. Silva EJ, Souza LG, Silva LAD, Taveira SF, Guilger RC, Liao LM, Junior LHKQ, Santana MJ, Marreto RN. A novel polymer-lipid hybrid nanoparticle for the improvement of topotecan hydrochloride physiochemical properties. Current Drug Delivery 2018; 15(7): 979-986. 
6. Raj S, Khurana S, Choudhari R, Kesari KK, Kamal MA, Garg N, Ruokolainen J, Das BC, Kumar D. Specific targeting cancer cells with nanoparticles and drug delivery in cancer therapy. Seminars in Cancer Biology 2021; 69: 166-177. doi: 10.1016/j.semcancer.2019.11.002

7. Ruman U, Fakurazi S, Masarudin MJ, Hussein MZ. Nanocarrier-Based Therapeutics and Theranostics Drug Delivery Systems for Next Generation of Liver Cancer Nanodrug Modalities. International Journal of Nanomedicine 2020; 15: 1437-1456. doi: 10.2147/IJN.S236927

8. https://www.cancerresearchuk.org/about-cancer/canceringernal/treatment/cancer drugs/drugs

9. Kakde D, Jain D, Shrivastava V, Kakde R, Patil AT. Cancer Therapeutics- Opportunities, Challenges and Advances in Drug Delivery. Journal of Applied Pharmaceutical Science 2011; 01 (09): 01-10.

10. https://patents.google.com/patent/US4622952A/en

11. https://patents.google.com/patent/US20040248858A1/en

12. https://data.epo.org/gpi/EP0266038B1

13. https://patents.google.com/patent/RU2440158C2/en

14. https://yandex.ru/patents/doc/RU2654764C2_20180522

15. https://patenton.ru/patent/RU2723882C2

16. https://patenton.ru/patent/RU2723884C2

17. https://yandex.ru/patents/doc/RU2239464C2_20041110

18. https://patents.google.com/patent/US8465533B2/en

19. https://patents.google.com/patent/US20070239213

20. https://patents.google.com/patent/US4846782A/en

21. https://www.freepatentsonline.com/4323056.html

22. https://patents.google.com/patent/ US5468223A/en

23. https://patents.google.com/patent/ US20040068296A1/en

24. https://patents.google.com/patent/ US5807257A/en

25. Xie M, Liu J, Tsao R, Wang Z, Sun B, Wang J. Whole Grain Consumption for the Prevention and Treatment of Breast $\begin{array}{lll}\text { Cancer. Nutrients } 2019 ; & 11(8):\end{array}$ doi:10.3390/nu11081769

26. Li Y, Li S, Meng X, Gan RY, Zhang JJ, Li HB. Dietary Natural Products for Prevention and Treatment of Breast Cancer. Nutrients 2017; 9(7): 728.

27. Kumar S, Prashar D. An analysis on changing trends of foodgrains in Himachal Pradesh International Journal of Pharmacy and Life Sciences 2012; 3(6): 1739-1742.

28. Butler LM, Wu AH, Wang R, Koh WP, Yuan JM, Yu MC. A vegetable-fruit-soy dietary pattern protects against breast cancer among postmenopausal Singapore Chinese women. American Journal of Clinical Nutrition 2010; 91(4): 10131019.

29. Kumar S, Barik K, Prashar D. Cropping and land use pattern in Himachal Pradesh: Case of district Solan. International Journal of Current Research and Review 2012; 04 (03): 19-25.

30. https://www.aicr.org/cancer-prevention/food-facts/wholegrains/
31. Fouladi F, Steffen KJ, Mallik S. Enzyme-Responsive Liposomes for the Delivery of Anticancer Drugs. Bioconjugate Chemistry 2017; 28(4), 857-868.

32. Sapra P, Allen TM. Ligand-targeted liposomal anticancer drugs. Progress in Lipid Research 2003; 42(5): 439-462.

33. Shim G, Han S, Yu Y, Lee S, Lee HY, Kim K, Kwon IC, Park TG, Kim YB, Choi YS, Kim CW, Oh YK. Trilysinoyl oleylamide-based cationic liposomes for systemic co-delivery of siRNA and an anticancer drug. Journal of Controlled Release 2011; 155(1): 60-66.

34. Kim JH, Kim YS, Park K, Lee $S$, Nam HY, Min KH, Jo HG, Park JH, Choi K, Jeong SY, Park RW, Kim IS, Kim K, Kwon IC. Antitumor efficacy of cisplatin-loaded glycol chitosan nanoparticles in tumor-bearing mice. Journal of Controlled Release 2008; 127(1): 41-49.

35. Feng $C$, Wang Z, Jiang C, Kong $M$, Zhou X, Li Y, Cheng X, Chen $X$. Chitosan/o-carboxymethyl chitosan nanoparticles for efficient and safe oral anticancer drug delivery: In vitro and in vivo evaluation. International Journal of Pharmaceutics 2013; 457 (1): 158-167.

36. Kim K, Oh KS, Park DY, Lee, Beom Suk Lee JY, Kim IS, Kim K, Kwon IC, Kim SY, Yuk SH. Doxorubicin/gold-loaded core/shell nanoparticles for combination therapy to treat cancer through the enhanced tumor targeting. Journal of Controlled Release 2016; 228: 141-149.

37. Xiang J, Li Y, Zhang Y, Wang G, Xu H, Zhou Z, Tang J, Shen Y. Polyphenol-cisplatin complexation forming core-shell nanoparticles with improved tumor accumulation and dualresponsive drug release for enhanced cancer chemotherapy. Journal of Controlled Release 2021; 330: 992-1003.

38. Kim J, Shim M, Yang S, Moon Y, Song S, Choi J, Kim j, Kim K. Combination of cancer-specific prodrug nanoparticle with $\mathrm{Bcl}-2$ inhibitor to overcome acquired drug resistance. Journal of Controlled Release 2021; 330: 920-932.

39. Yihan Y, Yunxiang Z, Lihong L, Yanyan X, Qiang C, Shijie YW, Yongchuan D, Jianmin Z, Anwen S. Nanoparticle-Based Drug Delivery in Cancer Therapy and Its Role in Overcoming Drug Resistance. Frontiers in Molecular Biosciences 2020; 7: 193.

40. Xu Y, Zhang Z, Wang $H$, Zhong $W$, Sun $C$, Sun $W, W u ~ H$. Zoledronic Acid-Loaded Hybrid Hyaluronic Acid/Polyethylene Glycol/Nano-Hydroxyapatite Nanoparticle: Novel Fabrication and Safety Verification. Frontiers in Bioengineering and Biotechnology 2021;9:629928. 10.3389/fbioe.2021.629928

41. Aguilar AEM, Fagundes AP, Macuvele DL, Cesca K, Porto L, Padoin N, Soares C, Riella HG. Green synthesis of nano hydroxyapatite: morphology variation and its effect on cytotoxicity against fibroblast. Materials Letters 2020; 284: 129013. doi: 10.1016/j.matlet.2020.129013

42. Au KM, Satterlee A, Min Y, Tian X, Kim YS, Caster JM, Zhang L, Zhang $\mathrm{T}$, Huang $\mathrm{L}$, Wang Az. Folate-targeted $\mathrm{pH}$-responsive calcium zoledronate nanoscale metal-organic frameworks: turning a bone antiresorptive agent into an anticancer therapeutic. Biomaterials 2016; 82: 178-193. doi: 10.1016/j.biomaterials.2015.12.018

43. Dai CF, Li SP, Li XD. Synthesis of nanostructured methotrexate/hydroxyapatite: morphology control, growth mechanism, and bioassay explore. Colloids and Surfaces 
B: Biointerfaces 2015; 136: 262-271. doi: 10.1016/j.colsurfb.2015.09.015

44. Federman N, Chan J, Nagy JO, Landaw EM, McCabe K, Wu AM, Triche T, Kang HG, Liu B, Marks JD, Denny CT. Enhanced growth inhibition of osteosarcoma by cytotoxic polymerized liposomal nanoparticles targeting the alcam cell surface receptor. Sarcoma 2012:126906. doi: 10.1155/2012/126906

45. Li X, Valdes SA, Alzhrani RF, Hufnagel S, Hursting SD, Cui Z. Zoledronic acid-containing nanoparticles with minimum premature release show enhanced activity against extraskeletal tumor. ACS Applied Material Interfaces 2019; 11:7311-7319. doi: 10.1021/acsami.8b16588

46. Sun H, Liu S, Zeng X, Meng X, Zhao L, Wan Y. Morphology effect of nano-hydroxyapatite as a drug carrier of methotrexate. Journal of Materials Science: Materials in Medicine 2017; 28:158. doi: 10.1007/s10856-017-5978-4

47. Yang X, Zhai D, Song J, Qing R, Wang B, Ji J, Rhein-PEG-nHA conjugate as a bone targeted drug delivery vehicle for enhanced cancer chemoradiotherapy. Nanomedicine 2020; 27:102196. doi: 10.1016/j.nano.2020.102196

48. Chuan D, Mu M, Hou H, Zhao N, Li J, Tong A, Zou B, Chen H, Han B, Guo G. Folic acid-functionalized tea polyphenol as a tumor-targeting nano-drug delivery system, Materials and Design, 2021, 109805 (In press)

49. Fan RR, Tong AP, Li XL, Gao X, Mei L, Zhou LX, Zhang $X N$, You C, Guo G. Enhanced antitumor effects by docetaxel/LL37 loaded thermosensitive hydrogel nanoparticles in peritoneal carcinomatosis of colorectal cancer International Journal of Nanomedicine 2015; $10: 7291-7305$.

50. Kumar DSRS, Senthikumar P, Surendran L, Sudhagar B. Ganoderma Lucidum-Oriental Mushroom Mediated Synthesis Of Gold Nanoparticles Conjugated With Doxorubicin And Evaluation Of Its Anticancer Potential On Human Breast Cancer Mcf-7/Dox Cells. International Journal of Pharmacy and Pharmaceutical Sciences 2017; 9(9): 267274.doi:10.22159/ijpps.2017v9i9.20093

51. Momin T, Gulbake A. Development and characterization of Doxorubicin and siRNA encapsulated chitosan nanoparticles. International Journal of Applied Pharmaceutics 2020; 12(4): 53-56.

52. Theivarasu $\mathrm{C}$, Indumathi T. Effect Of $\mathrm{Ce}^{3+}$ Metal lons On The Antibacterial And Anticancer Activity Of Zinc Oxide Nanoparticles Prepared By co-precipitation Method. Asian Journal of Pharmaceutical and Clinical Research 2017;10: 388-392.

53. Vasanth N, Melchias G, Kumaravel P. Biogenic Silver Nanoparticles Mediated by Broussonetia Papyrifera: Anticancer and Antimicrobial Activity Against Pathogenic Organisms. Asian Journal of Pharmaceutical and Clinical Research 2017; 10 (5):93-98.

54. Athira GK, Jyothi AN. Preparation And Characterization Of Curcumin Loaded Cassava Starch Nanoparticles With Improved Cellular Absorption. International Journal Of Pharmacy And Pharmaceutical Sciences 2014; 6(10): 171176.

Source of Support: The author(s) received no financial support for the research, authorship, and/or publication of this article.

Conflict of Interest: The author(s) declared no potential conflicts of interest with respect to the research, authorship, and/or publication of this article.

For any question relates to this article, please reach us at: editor@globalresearchonline.net New manuscripts for publication can be submitted at: submit@globalresearchonline.net and submit_ijpsrr@rediffmail.com 